\title{
A Qualitative Study on Muslim Entrepreneur Perspective on CSR
}

\author{
Soepatini $^{1}$, Reynaldo Purnomo Putra ${ }^{2}$ \\ \{soepatini@ums.ac.id ${ }^{1}$, reynaldopurnomo@gmail.com ${ }^{2}$ \} \\ Universitas Muhammadiyah Surakarta, Indonesia
}

\begin{abstract}
Muslim community desire to work and strive in accordance with Islamic values are increasing, including their CSR practices. However, the concept of Islamic CSR has not been formally and systematically arranged. This study examines Muslim entrepreneurs' attitude towards CSR by using qualitative methods in order to gain a better understanding regarding the issue of CSR in Islam. Samples consisted of three participants of Muslim entrepreneurs who have done CSR in their business. Data collecting techniques in this study were using in-depth interview techniques. Thematic analysis method was employed to look for pattern and themes within the data. The result of the study found that Muslim entrepreneur perceptions of CSR are ethic and philanthropic responsibility. The benefit perceived is a better image for their company. Zakat is used as their guide to implement CSR program. Longevity and correlativity of the program is seen as an effectivity in CSR program.
\end{abstract}

Keywords: Corporate Social Responsibility, Islamic CSR, Muslim Entrepreneur, Benefit, Implementation, Effectivity.

\section{Introduction}

Business corporations have complex relationships with many individual and organization in societies. Building positive and mutually beneficial relationships with an organization can help a company's reputation and address critical social and ethical issues ${ }^{[1]}$. Generally, the main objective of doing business is to achieve their economic goal, in other words, generate maximum profits for stakeholders. However, as of now, many companies are making their social goals as one of the components of overall business operation, some companies have even integrated their social and economic goals as their primary mission. Understanding that businesses carry broad responsibilities to society while they pursue their economic goals is an understanding that has existed from the old-age. Both market and nonmarket stakeholders expect that the business is undertaken with social responsibility ${ }^{[1]}$.

CSR is a form of corporate responsibility for development of an established economy in an effort to improve the quality of people's lives and the environment ${ }^{[2]}$. Corporate social responsibilities (which will be referred to as CSR for the rest of the paper) is increasingly becoming an important issue in the business world. Radical changes to the relationship between companies and communities can be seen in the last thirty years. One of the keys that drive these changes is the issue of the importance of harmonious relations between shareholders or stakeholders and the company ${ }^{[3]}$. 
Every company manage to implement CSR based on ethical values, culture, and beliefs that apply in the society of one country ${ }^{[2]}$. Understanding CSR from the Muslim entrepreneur perspective is necessary. It is because Islam is the second-largest religion in the worldand is experiencing rapid growth compared to other religions. This rapid growth is in line with the increasing desire of the Muslim community to work and strive in accordance with Islamic values $^{[4]}$. Although from a philosophical point of view, Islam discuss a lot regarding social responsibility ${ }^{[4]}$, it's important to understand what is Muslimentrepreneurs ' perceptions of CSR, the benefits Muslim entrepreneurs perceived, how Muslim entrepreneurs implement the program in their company, and how Muslim entrepreneurs perceive the effectivity of CSR.

\section{Literature Review}

The root of CSR come from the concept of ethics, which is a discipline that examine moral standards of an induvidual or a society ${ }^{[5]}$. It could also be defined as the set of moral principles or values that defined right and wrong for a person or a group ${ }^{[6]}$. Business ethics is a specialized study of moral right and wrong ${ }^{[5]}$. According to Habibah, akhlaq are Islamic concept of ethics, which is a knowledge that explains about right and wrong, regulating social relationship, and determine the ultimate goal of the business and work ${ }^{[7]}$. Business ethics in Islam is an ethical business conduct which is wrapped in sharia values that endorse halal and haram with Qur'an and Sunnah as its main sources ${ }^{[8]}$. Apart from that, business experience from Prophet Muhammad before he was appointed as the last prophet can also be taken as a business ethics ${ }^{[9]}$.

The principle of charity and stewardship by Carnegie in 1998 become the basic for many CSR definition ${ }^{[10]}$. A more contemporary definition of CSR by Archie Carroll argue that "four kinds of social responsibilities continue total CSR: economic, legal, ethical and philanthropic ${ }^{[11] “}$. Before law regarding investment (penanaman modal) and limited company (perseroan terbatas) was updated, CSR is an unwritten ethic of business in Indonesia, however, after the update of the law companies that stand in Indonesia is required to perform $\mathrm{CSR}^{[2]}$. A large number of study have mentioned the benefits of implementing CSR for

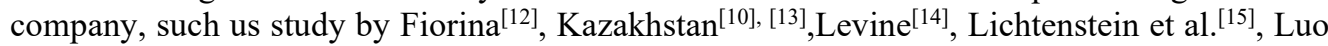
$\&$ Bhattacharya ${ }^{[16]}$, and study by Parguel et al. ${ }^{[17]}$.

Zakat, Infaq, Sadaqah and Waqf are repeatedly mentioned in developing concept of CSR in Islam. These four philanthropies have something in general, that they are valued as a form of devotion and deepen the solidarity between people ${ }^{[18]}$. Islamic CSR concept has not been formally and systematically arranged and stated. However, some researchers have conducted studies on the study of CSR in Islam which aimed to formulate the concept of CSR in Islam, also looking at the values of CSR equality in Islam with the concept of CSR developing in the West $^{[4]}$. A notable study done by Javaid and Al-Malkawi stated that the concept of Zakat is not only can be used as CSR measurement, but also resulting in better CSR ${ }^{[19]}$.

The effectiveness of CSR program are affected by unique factors for each unique individual CSR program according to study done by Irwanto and Prabowo ${ }^{[20]}$. While a comprehensive study on the barriers to CSR implementation is lacking ${ }^{[21]}$, there are however, some relevant studies in regard of the hindrance of implementing CSR such as the study by Thongthippa ${ }^{[22]}$, Guedes et al. ${ }^{[23]}$, and J.Hsu and M.Cheng ${ }^{[24]}$. 


\section{Method}

\subsection{Data}

Primary data were obtained from in-depth interview. Data collecting method used in this study is interview techniques. The level of structure of the interview used in this research is semi-structured. For the research, researcher prepare six general question for the participants.

Purposive sampling or Judgmental sampling was used to gather the data needed for the research. The individual selected to be the interview participants are Muslim entrepreneurs who have applied CSR in their business and willing to share their information regarding their company and its CSR program.

\subsection{Methodology}

To achieve the purpose of the study, qualitative interpretive method was chosen. Additionally, in order to address the gaps in current literature it was decided this research should focus on identifying theme within the participants understanding as it would provide for the researcher with scope for further investigation of the subject in question. It was decided the most appropriate method of analysis would be a thematic analysis suggested by Braun \& Clarke $^{[25]}$. This method is used to consider the flexibility of the method. Thematic analysis method is flexible in terms of theoretical framework, research questions, methods of data collection and sample size ${ }^{[25]}$.

\section{Result And Discussion}

\subsection{Result}

The thematic analysis process was applied to the transcripts elicited key concepts were evident in the data. These themes are viewed as essential in determining and understanding of all the participants. These categories labelled as: 1.) Muslim Entrepreneurs perceptions on CSR, 2.) People's perception of the Company as the Most Perceived Benefit of CSR, 3.) ZIS (Zakat,Infaq, and Sadaqah) as CSR Implementation Guidance, 4.) Longevity, Correlativity, as an Effectivity of CSR, and 5.) Difficulties in Implementing Effective CSR. There are course aspects of the participants' understandings that overlap across these categories. This, however, should be viewed as a good interpretation of understanding and attitude in general. Which is never made up of isolated concepts, but are all relative to each other. The results above highlight Muslim entrepreneur perspective on CSR in terms of their understanding, benefit, implementation and effectivity of CSR program.

\subsection{Discussions}

All participants view CSR as ethic and philanthropic responsibilities, these are two out of four kinds of social responsibilities argued by Archie Carroll ${ }^{[11]}$. The participants mentioned that their CSR is a form of company's responsibility and duty because they are involved in a community or society, therefore there are people rights in their activities. According to ethics in Islam ${ }^{[7]}$, this sentiment justifies as an ethical behavior. Some ethical relativism issue shows up as one of the participants views that CSR is also a good media to spread religious beliefs, this view can be seen as an unethical in places where the majority of the people are not 
Muslim nor religious. All participants stated that they have a sense of satisfaction when helping others, and they did it with sincerity and strong helping intention. The participants implement CSR by purely voluntary actions because they are concerned for other people's condition, or in other word, they did it because of philanthropic responsibilities.

In addition, they determine CSR as a motivation to do better with their business so that they can maintain and expand their CSR program. However, their view on CSR are incomplete because their view of CSR does not include economic and legal responsibilities as mentioned by Archie Carroll.The benefit perceived by the participants is their CSR program will make a better perception for the company.

From shaping up people's assumption that caused by the program, it will in turn position their company in a better place within their mind. With this, the participants felt that the consumer will take this as a consideration in their decision making. This in line with previous study by Lichtenstein et al. ${ }^{[15]}$ that CSR could increase sale and purchase behavior. Since Zakat is an obligation for Muslim, and the participants have a responsibility to carry out CSR program, and they see this as coinciding interest. Therefore, their implementation of CSR programs is guided by Zakat commandment. With this guide, it made them clear on how much they have to spend and who will receive the help from their CSR program.

One of the participants specify that he and his business circle made an optimization to the Zakat application. They added up the minimum number to $10 \%$ to ensure that the $2.5 \%$ requirement are met. The implementation of CSR using Zakat as guide was proven to be successful in the previous study done by Javaid and Al-Malkawi ${ }^{[19]}$.

Participants idea of effective CSR determined from the benefits of what they provide to the people affected by the program. The participants argued that with implementing the program this way, it will be more impactful than the other way around. According to the participants, CSR program could be considered effective if what they provide was long-term and related to the business activities they were undertaking. Parguel et al. study stated that sustainable CSR could effectively deter 'greenwashing' label for the company, or in other words, people will see the company as an actual organization that is socially responsible ${ }^{[17]}$

Despite it will be more effective, it comes with its' own difficulties. Expensive and demanding seems to be the internal difficulty the participants encounter in implementing an effective CSR. The external difficulty in implementing an effective CSR is that the harsh economy condition that people are experiencing throughout the country. Several previous studies supported the idea that are factors that hinder the implementation of CSR, most of the them are also in line with the participant's statements.

Thongtippha'sstudy stated that the barrier for SMEs in Thailand to implement CSR program are the restrictive amount of budget and time they had ${ }^{[22]}$. Another study by J. Hsu and M. Chengalso found that cost and time to be the barrier in implementing $\operatorname{CSR}^{[24]}$. Additionally, the study by Guedes et al. show that the major barrier to implement CSR for SMEs are cost and lack of human resources ${ }^{[23]}$. 


\section{Conclusion}

\subsection{Summary and Implication}

From the previous chapter, we found out Muslim entrepreneurs' perception of CSR. Muslim entrepreneur determines CSR as an ethic and philanthropic responsibility. They implement CSR as a sense of responsibility and duty as an organization that involved in society. Apart from responsibility and duty, they implement CSR out of concern for others and make it as a motivation for their activity so they can carry out their activities to be more productive in order to sustain and expand their CSR program.

The benefit that perceived by Muslim entrepreneur for implementing CSR is that it will make a better image of the company. From shaping up people's assumption that caused by the program, it will in turn position their company in a better place within their mind. With this, the participants felt that the consumer will take this as a consideration in their decision making.

In implementing CSR, Muslim entrepreneur use ZIS as a guideline due to a commandment in Islam that interrelated with their responsibility and duty as an organization or company.

Muslim entrepreneurs' viewpoint of effective CSR is determined by the benefits felt by the people that receive their aids. They stated that if the benefit that perceived by the people is everlasting and related to their activity, their program will become more apparent to the public and in turn will generate more benefit for the company that implement the CSR this way. However, implementing these CSR come with internal and external difficulty.

This study implies that Muslim entrepreneur CSR program are influenced by their beliefs of their religion. The study also implies that Muslim entrepreneur understanding CSR are incomplete in the context of Archie Carroll's four kind of social responsibilities.

As research in regard of CSR in Islamic viewpoint are scarce, this paper is expected to be a stepping stone for further research on CSR in terms of Islamic religion.This paper is also a contribution to theory and practice of CSR in the field of management and Islamic economic.

\subsection{Limitation and Suggestion}

The writer contemplates that the analysis in this study is far from perfect due to some limitation. There are deficiencies in this study such as that the study might not represent the subject as a whole population even though it reach a saturation due to the difficulties in finding the subject that meet the criteria, the inability to meet face-to-face with the participants may affecting their answer, and lastly there are inadequate amount of previous study of several topics.

It can be suggested for further research to investigate the influence of CSR on organizational performance of Muslim entrepreneurs. A sample of entrepreneurs who have no experience in implementing CSR also will be an interesting topic for future research .

\section{References.}

[1] A. Lawerence, J. Weber, and J. Post, "Business and Society: Stakeholders, Ethics, Public Policy," in Business and Society: Stakeholders, Ethics, Public Policy. 13th International Edition McGraw Hill, 2014.

[2] T. Mardikanto, CSR (Corporate Social Responsibility)(Tanggungjawab Sosial Korporasi). 
Bandung: Alfabeta, 2014

[3] B. Azheri, Corporate social responsibility: Dari voluntary menjadi mandatory. RajaGrafindo Persada, 2011.

[4] M. Yasir Yusuf, Islamic Corporate Social Responsibility (I-CSR). Kencana, 2017.

[5] M. G. Velasquez, Business Ethics Concepts and Cases. 2014.

[6] W. C. Frederick and K. Davis, Business and society: corporate strategy, public policy, ethics. New York: McGraw-Hill, 2002.

[7] S. Habibah, "Akhlak Dan Etika Dalam Islam,” J. Pesona Dasar, vol. 1, no. 4, pp. 73-87, 2017.

[8] F. Amalia, "ETIKA BISNIS ISLAM: KONSEP DAN IMPLEMENTASI PADA PELAKU USAHA KECIL," Al-Iqtishad J. Islam. Econ., vol. 6, no. 1, Jan. 2014, doi: 10.15408/ijies.v6i1.1373.

[9] M. Saifullah, "ETIKA BISNIS ISLAMI DALAM PRAKTEK BISNIS RASULULLAH," Walisongo J. Penelit. Sos. Keagamaan, 2011, doi: 10.21580/ws.19.1.215.

[10] Y. Smirnova, "Perceptions of corporate social responsibility in Kazakhstan," Soc. Responsib. J., 2012, doi: 10.1108/17471111211247974.

[11] A. B. Carrol, "The pyramid of corporate social responsibility: Toward the moral management of organizational stakeholders.," 1991.

[12] C. Fiorina, "A World of Change," 2001.

[13] D. Kazakhstan, "O socialnoi otvetstvennosti biznesa,” vol. 13, p. 1, 2010.

[14] M. A. Levine, "The Benefits of Corporate Social Responsibility," N. Y. Law J., vol. 13, 2008.

[15] D. R. Lichtenstein, M. E. Drumwright, and B. M. Braig, "The effect of corporate social responsibility on customer donations to corporate-supported nonprofit," Journal of Marketing. 2004, doi: 10.1509/jmkg.68.4.16.42726.

[16] X. Luo and C. B. Bhattacharya, "Corporate social responsibility, customer Satisfaction, and market value," J. Mark., 2006, doi: 10.1509/jmkg.70.4.1.

[17] B. Parguel, F. Benoît-Moreau, and F. Larceneux, "How Sustainability Ratings Might Deter 'Greenwashing': A Closer Look at Ethical Corporate Communication," J. Bus. Ethics, 2011, doi: 10.1007/s10551-011-0901-2.

[18] Q. Uyun, "ZAKAT, INFAQ, SHADAQAH, DAN WAKAF SEBAGAI KONFIGURASI FILANTROPI ISLAM,” Islam. J. Stud. Islam, 2015, doi: 10.19105/islamuna.v2i2.663.

[19] S. Javaid and H. A. N. Al-Malkawi, "Corporate social responsibility and financial performance in Saudi Arabia: Evidence from Zakat contribution," Manag. Financ., 2018, doi: 10.1108/MF12-2016-0366.

[20] A. Irwanto and A. Prabowo, "Kajian Efektivitas Program Corporate Social Responsibility (CSR) Yayasan Unilever Indonesia," J. Manaj., 2009.

[21] K. F. Yuen and J. M. Lim, "Barriers to the Implementation of Strategic Corporate Social Responsibility in Shipping," Asian J. Shipp. Logist., vol. 32, no. 1, pp. 49-57, 2016, doi: 10.1016/j.ajs1.2016.03.006.

[22] T. Viriyapan, "A STUDY OF CSR-IN-PROCESS PRACTICES: THE CASE OF THAI SMEs.," UTCC Int. J. Bus. Econ., 2014.

[23] G. Guedes, F. Ferreira, L. Urbano, and A. Marques, "Corporate social responsibility: Competitiveness in the context of textile and fashion value chain," Environ. Eng. Manag. J., 2017, doi: 10.30638/eemj.2017.125.

[24] J. L. Hsu and M. C. Cheng, "What Prompts Small and Medium Enterprises to Engage in Corporate Social Responsibility? A Study from Taiwan," Corp. Soc. Responsib. Environ. Manag., 2012, doi: 10.1002/csr.276.

[25] V. Braun and V. Clarke, "Using thematic analysis in psychology," Qual. Res. Psychol., 2006, doi: 10.1191/1478088706qp063oa. 